Pak. j. sci. ind. res. Ser. A: phys. sci. 2020 63A(3) 147-152

\title{
Effect of Immersion Mediums on the Structural and Thermal Properties of $\left[\mathrm{EP} / \mathrm{ZrO}_{2}-\mathrm{Y}_{2} \mathrm{O}_{3}\right]$ Nanocomposites
}

\author{
Ahmad H. M. Al-Falahi \\ Physics Department, College of Education for Pure Sciences, University of Anbar, Iraq
}

(received December 03, 2018; revised July 29, 2019; accepted September 4, 2019)

\begin{abstract}
This research studies is the effects of the chemical solutions on the structural properties and thermal conductivity of the nanocomposite materials. Samples were prepared via the hand lay-up molding method, using epoxy resin as a matrix and a variety of weight ratios of the nanoceramic powder (ZirconiaYttria) as a reinforcement material with different weight ratios, using hand lay-up molding method. Distilled water $\mathrm{H}_{2} \mathrm{O}$ and diluted $\mathrm{HCl}$ and $\mathrm{NaOH}$ solutions were used as immersion mediums. Surface roughness, granularity cumulating distribution and thermal conductivity were investigated. The results showed an increase in the surface roughness and changes in the granularity cumulating distribution and thermal conductivity that were dependent on the type of immersion medium used, as well as on the addition ratio of Zirconia-Yttria.
\end{abstract}

Keywords: epoxy resin, ceramic powder, roughness, granularity, thermal conductivity

\section{Introduction}

Due to wide use of composite materials in a variety of industrial, civil and military fields, the characteristics of these materials have been seen as a high importance and received the attention of researchers. Polymeric composites, especially particulates are modern materials that play an important role in most engineering and technological applications (Autra, 2006). The shape and size of the particles in these composites and their distribution in the matrix material in addition to and within the interface region. The bond between the polymer and the particles all affect the final properties of the composite material (Zaman et al., 2012). There are several types of composite materials which are polymeric composites and easy to manufacture, low cost, light weight, have good thermal and electrical insulation and other good physical properties, metallic composites, which have a high strength and toughness that is higher, stronger and tougher than the polymeric or ceramic composites but limited in use because of their high weight. The ceramic composite are characterized by their tolerance to high temperatures and resistant to confirmation, therefore it is widely used in the manufacture of turbine blades in the aerospace industries (e.g. as rocket nozzles or and in fine electronic industries), but it is also brittle materials (Callister, 2007). To obtain the best clinical performance in dental restoration, the need for biomaterials with anti-microbes

*Author for correspondence;

E-mail: eps.ahmedh.mnajid@uoanbar.edu.iq properties has been emerged. It is important to evaluate the effect of chemical media on the rough surface of polymeric composites, due to the binding bacterial adhesion and surface roughness (Cintia et al., 2012).

Polymers are poor thermal conductors because they do not have free electrons, so heat transfer depends on the vibration or rotation of chain molecules. The heat transmitted by elastic waves called phonons (Hameed, 2016). Thermal conductivity follows Fourier's laow, provided below as in equation 1 (John, 2000).

$$
Q=-K A\left[\frac{d T}{d x}\right]
$$

where:

$\mathrm{Q}$ is the quantity of passing heat (w); K is the thermal conductivity coefficient $\left(\mathrm{w} / \mathrm{m} .{ }^{0} \mathrm{k}\right)$; A is the section area of heat flow $\left(\mathrm{m}^{2}\right)$ and $\mathrm{dt} / \mathrm{dx}$ is the thermal gradient $\left({ }^{0} \mathrm{k} / \mathrm{m}\right)$.

\section{Materials and Methods}

Samples preparation. Samples of composites were prepared by using epoxy resin type (EUXIT 50) (made by SWISSCHEM), as a matrix, and the commercially available nano ceramic powder [Zerconia- - Yttria, commercial, $\left.\left(\mathrm{ZrO}_{2} 97 \%-\mathrm{Y}_{2} \mathrm{O}_{3} 3 \%\right) 70-80 \mathrm{~nm}\right]$ as a reinforcement material, with weight fractions of (1.5, $2.5,3.5,4.5 \mathrm{wt} / \%)$. This epoxy resin is a thermoset polymer. It is a, transparent liquid, which has properties of adhesion, low shrinkage, a density of $1.03 \mathrm{~g} / \mathrm{cm}^{3}$ and 
can be turned into a solid state by adding a hardener with a blending rate of one part of hardener to three parts of epoxy (1:3) at a laboratory temperature. The composites were prepared using the hand lay-up molding method, then heat cured up to $55^{\circ} \mathrm{C}$. The samples were then cut according to the standard specifications. Distilled water $\mathrm{H}_{2} \mathrm{O}$ with diluted $\mathrm{HCL}$ and $\mathrm{NaOH}(0.5 \mathrm{~N})$ were used as immersion mediums.

The tests. There are three tests which used as composite samples as follows:

Atomic Force Microscopy Technique (AFM-contact mode) used to study the effect of the solutions on the surface roughness of the composites and granularity cumulating distribution before and after immersing the samples for 14 months. Samples of $1.5 \mathrm{wt} \%$ and 4.5 wt $\%$ were selected in for this test research.

Lee's disk method was used to determine the thermal conductivity $\mathrm{k}$ for the samples both before and after immersion (for the same period of immersion), $\mathrm{k}$ value was calculated according to using equation 2 (Macutkevic and Banys, 2013).

$$
\begin{aligned}
& \mathrm{K}\left\{\mathrm{T}_{\mathrm{B}}-\mathrm{T}_{\mathrm{A}} / \mathrm{ds}\right\}=\mathrm{e}\left[\mathrm{T}_{\mathrm{A}}+2 / \mathrm{r}\left\{\mathrm{d}_{\mathrm{A}}+1 / 4 \mathrm{ds}\right\} \mathrm{T}_{\mathrm{A}}\right. \\
& \left.+1 / 2 \mathrm{r} \mathrm{ds} \mathrm{T}_{\mathrm{B}}\right] \ldots \ldots \ldots \ldots \ldots \ldots \ldots \ldots \ldots \ldots \ldots \ldots \ldots \ldots \ldots \ldots \ldots \ldots \ldots \ldots \ldots \ldots \ldots \ldots \ldots
\end{aligned}
$$

where:

$\mathrm{e}=$ represents the amount of thermal energy $(\mathrm{H})$ passing through the disc per second $\left(\mathrm{W} / \mathrm{m}^{2} . \mathrm{k}\right)$, and is calculated from equation 3 .

$$
\begin{aligned}
& \mathrm{H}=\mathrm{IV}=\pi \mathrm{r}^{2} \mathrm{e}\left(\mathrm{T}_{\mathrm{A}}+\mathrm{T}_{\mathrm{B}}\right)+2 \pi \mathrm{re}\left[\mathrm{d}_{\mathrm{A}} \mathrm{T}_{\mathrm{A}}+\right. \\
& \left.\mathrm{ds} 1 / 2\left(\mathrm{~T}_{\mathrm{A}}+\mathrm{T}_{\mathrm{B}}\right)+\mathrm{d}_{\mathrm{B}} \mathrm{T}_{\mathrm{B}}+\mathrm{d}_{\mathrm{C}} \mathrm{T}_{\mathrm{C}}\right] \ldots \ldots \ldots(3)
\end{aligned}
$$

where:

$\mathrm{I}=$ current passed through the circuit; $\mathrm{V}=$ applied voltage; $T_{A}, T_{B}, T_{C}=$ temperatures of the discs $A, B$ \& $C$ respectively; $d_{A}, d_{B}, d_{C}=$ thicknesses of the discs $A$, $\mathrm{B} \& \mathrm{C}$, respectively; $\mathrm{ds}=$ sample's thickness and $\mathrm{r}=$ disc's radius.

\section{Results and Discussion}

It was found from the results of tests that an increase in the surface roughness of the samples occurred after immersion in the solutions than before immersion, as shown in Table 1 and Fig. 1 and 2. The solutions produced different amounts of erosion of the material's surface when different gradients were used with an unusual decrease in roughness being seen with an increasing ratio of $\mathrm{Zr} \mathrm{O}_{2}-\mathrm{Y}_{2} \mathrm{O}_{3}$ for in the case of the $\mathrm{NaOH}$ solution but an increase seen for the other two solutions (Ranta et al., 2017; Saijai et al., 2016).

Change in the granularity distribution was observed after immersion the samples in the solutions, and the results are as shown in Table 2 and Fig. 3 and 4. The water in composite material acting acted as a simple way to separate the matrix material from the reinforcement material and to therefore demonstrate that the granularity is high. Due to the chemical action of acids on polymers and ceramics, the granularity distribution appears to be smaller than it is, while the effect of the base solution is less than that of the acid, which is consistent with (Vouyovitch et al., 2006).

The thermal conductivity of the composite substance increases when the ratio of $\mathrm{ZrO}_{2}-\mathrm{Y}_{2} \mathrm{O}_{3}$ is increased before immersion because the ceramic material has a higher thermal conductivity than the polymer (Fig. 5) (Hadi and Alradha, 2016; Callister, 2007). After immersing the samples in the solutions, the thermal conductivity is reduced in the first weeks of the immersion period due to the changes in the material's structure. This leads to the dispersal of the phonons and thus the low thermal conductivity (Alqadhi, 2014; Ledjane and Marysiliva, 2009). As the period of immersion extends to the 8- and 12- week stages, the solutions are carried out through the interface region and the cracks already present in the material. The $\mathrm{H}_{2} \mathrm{O}$ creates a swelling process (Ledjane and Marysiliva,

Table 1. Variation of surface roughness with immersion

\begin{tabular}{llr}
\hline \hline Immersion medium & \multicolumn{2}{c}{ Average roughness } \\
\cline { 2 - 3 } & $1.5 \mathrm{wt} \%$ & $4.5 \mathrm{wt} \%$ \\
\hline Without immersion & $0.937 \mathrm{~nm}$ & $1.74 \mathrm{~nm}$ \\
$\mathrm{H}_{2} \mathrm{O}$ & $4.08 \mathrm{~nm}$ & $6.67 \mathrm{~nm}$ \\
$\mathrm{HCL}$ & $3.63 \mathrm{~nm}$ & $9.11 \mathrm{~nm}$ \\
$\mathrm{NaOH}$ & $12.6 \mathrm{~nm}$ & $10.1 \mathrm{~nm}$ \\
\hline \hline
\end{tabular}

Table 2. Granularity cumulating distribution

\begin{tabular}{lll}
\hline \hline Immersion medium & \multicolumn{2}{c}{ Average diameter } \\
\cline { 2 - 3 } & $1.5 \mathrm{wt} \%$ & $4.5 \mathrm{wt} \%$ \\
\hline Without immersion & $153.28 \mathrm{~nm}$ & $253.23 \mathrm{~nm}$ \\
$\mathrm{H}_{2} \mathrm{O}$ & $126.14 \mathrm{~nm}$ & $184.40 \mathrm{~nm}$ \\
$\mathrm{HCL}$ & $92.08 \mathrm{~nm}$ & $76.22 \mathrm{~nm}$ \\
$\mathrm{NaOH}$ & $113.26 \mathrm{~nm}$ & $85.12 \mathrm{~nm}$ \\
\hline
\end{tabular}


2009), while the $\mathrm{HCL}$ and $\mathrm{NaOH}$ solutions weaken the molecular bonding forces between the molecular chains, with the result that, for meaning the chains' mobility increases, facilitating the transfer of the phonons through the material and leading to an increase in its thermal

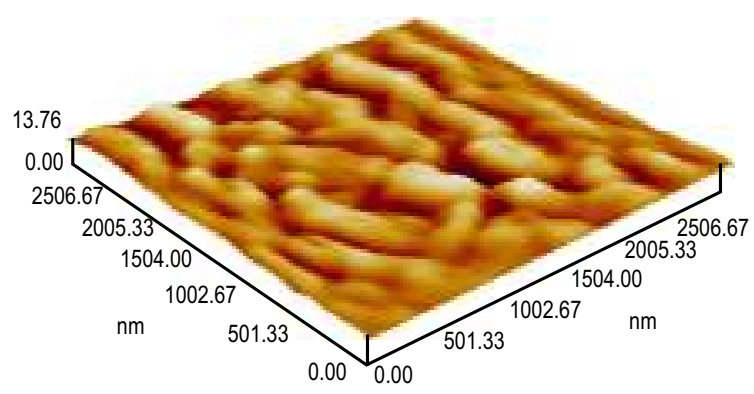

a- before immersion

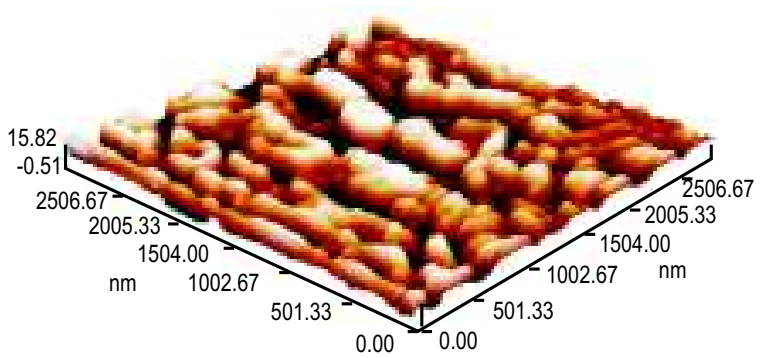

b- Immersion in $\mathrm{H}_{2} \mathrm{O}$

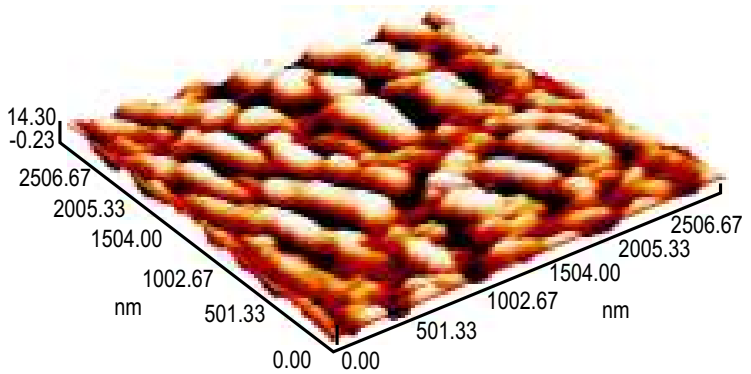

c- Immersion in $\mathrm{HCL}$

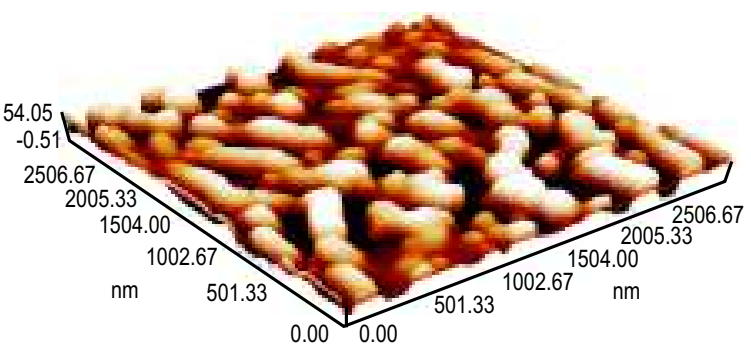

d-Immersion in $\mathrm{NaOH}$

Fig. 1. Variation of surface roughness with different immersion mediums (sample 1.5 $w t \%)$.
conductivity(Geon et al., 2006). Note that the effect of the solutions of $\mathrm{HCL}$ and $\mathrm{NaOH}$ are greater than the effect of the water $\mathrm{H}_{2} \mathrm{O}$ as chemical solutions corrosive and their interaction breaks the molecular bonds (Dheyaa and Mnajid, 2012 ).

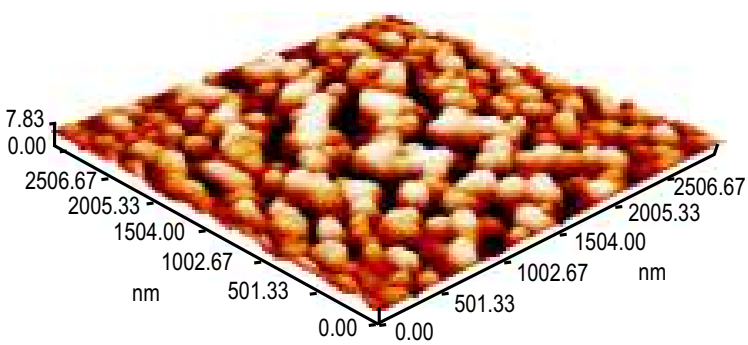

a- before immersion

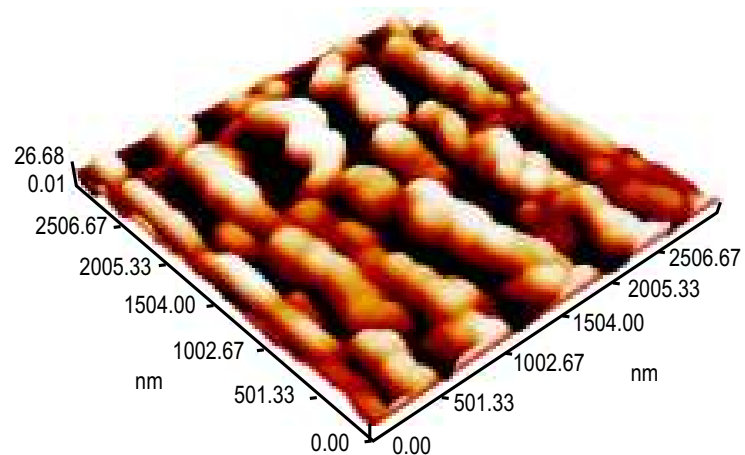

b- Immersion in $\mathrm{H}_{2} \mathrm{O}$

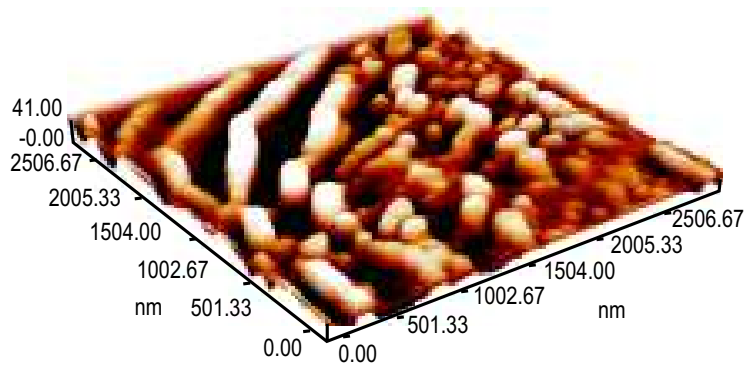

c- Immersion in HCL

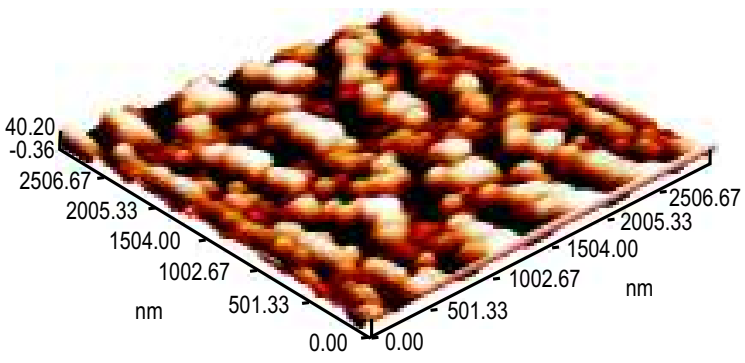

d-Immersion in $\mathrm{NaOH}$

Fig. 2. Variation of surface roughness with different immersion mediums (sample 4.5 wt \%). 

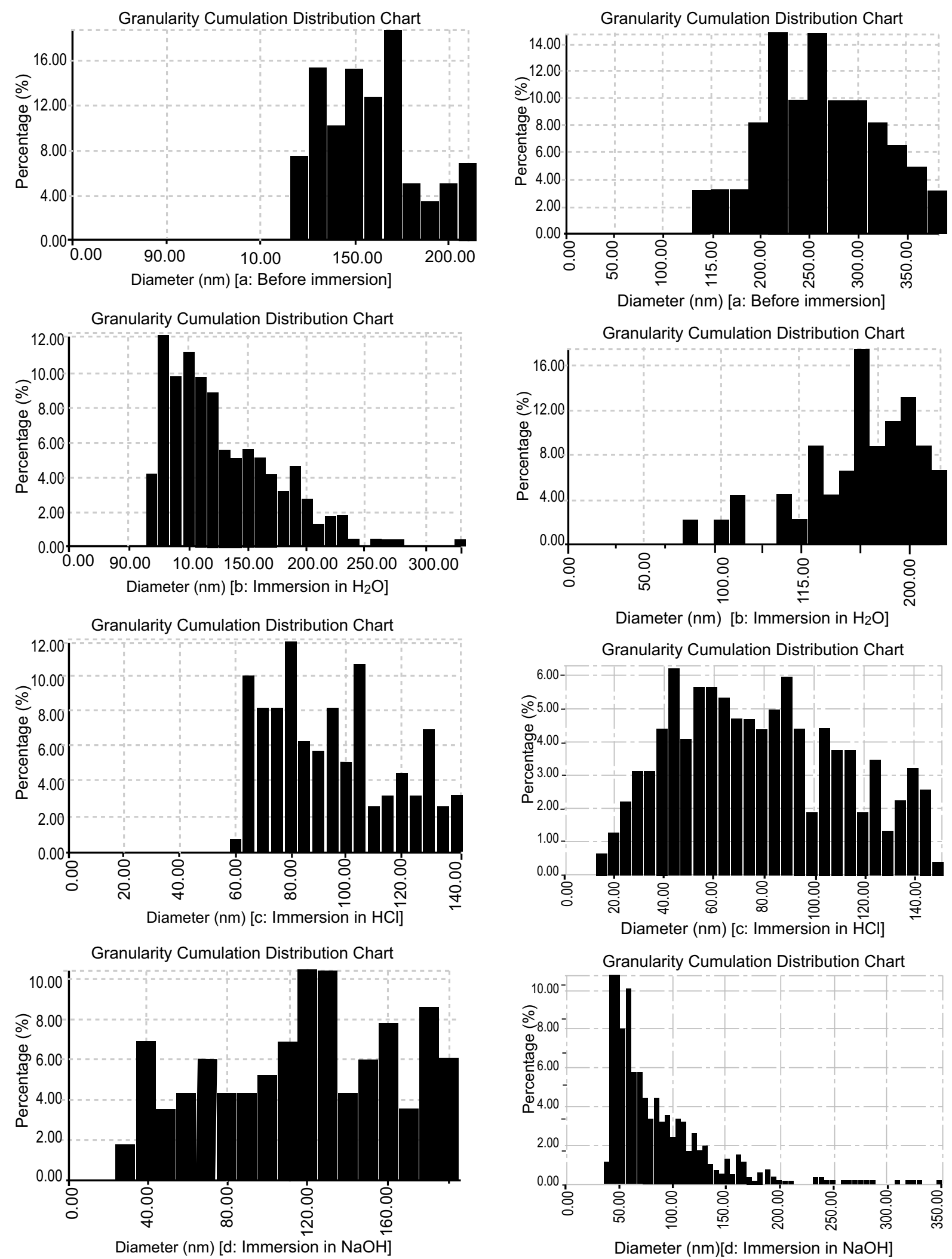

Fig. 3. Variations in theof granularity cumulating distribution with different immersion mediums (sample $1.5 \mathrm{wt} \%$ ).
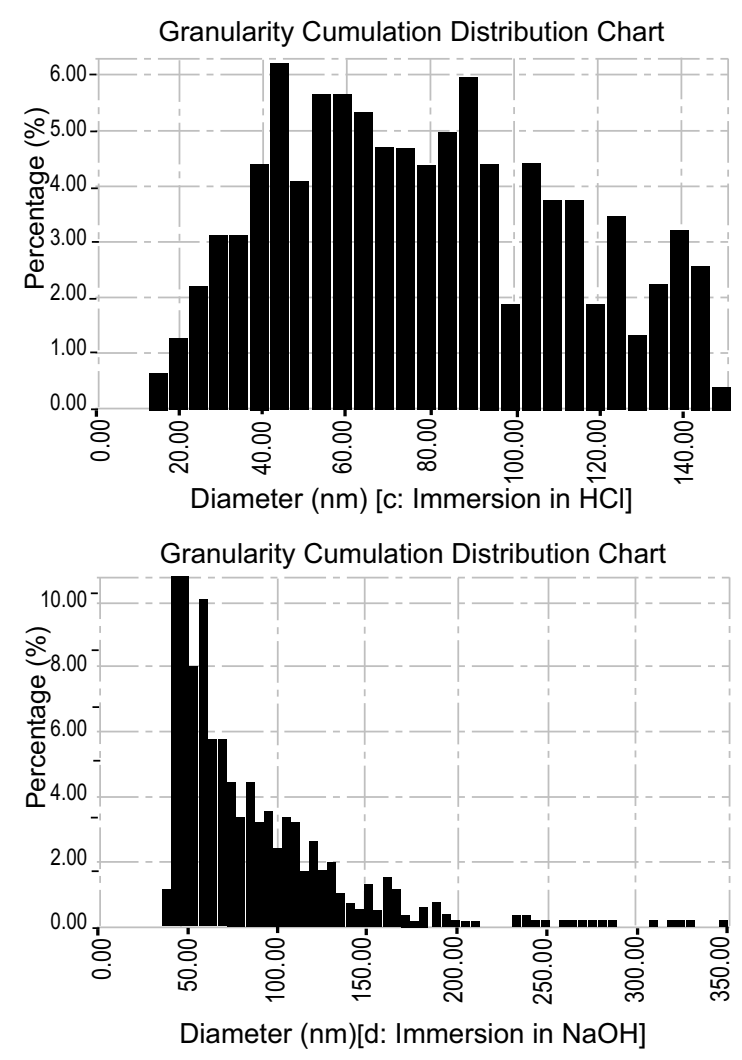

Fig. 4. Variations of in the granularity cumulating distribution with different immersion mediums (sample $4.5 \mathrm{wt} \%$ ). 

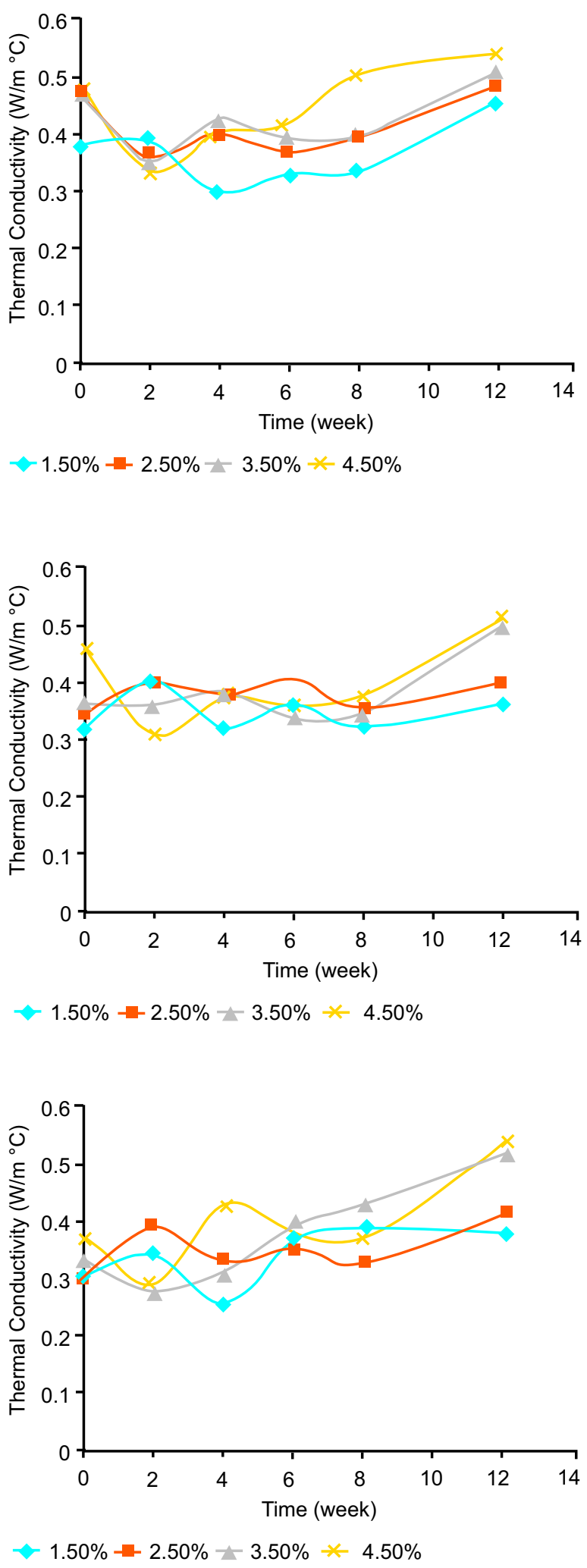

Fig. 5. K values with different conditions (medium, time, ratio wt \%).

\section{Conclusions}

The surface roughness and granularity distribution of the composite material is affected by both the ratio of the ceramic material to the polymer and the type of immersion medium used. This leads to an increase in the chemical resistancet of composite materials because the ceramic particles have high cheamical stabilities.

Different chemical solutions, have different effects on the composite material's structure and thermal conductivity, in a manner that changes with immersion time.

Increasing the ratio of ceramic powder added increases the surface roughness and thermal conductivity of composite material. This means that the effect of the high thermal conductivity coefficient of ceramics was evident on the thermal properties of the composite.

The effect of $\mathrm{NaOH}$ solution on the composite material is different from that of $\mathrm{HCL}$ and distilled $\mathrm{H}_{2} \mathrm{O}$ water.

Conflict of Interest. The authors declare no conflict of interest.

\section{References}

Autra, K.K. 2006. Mechanics of Composite Materials, $2^{\text {nd }}$ edition, Taylor \& Francis, IL, USA.

Alqadhi, M. 2014. The eEffect of water and crude oil on mechanical and thermal properties of epoxy -clay nanocomposites. Polymer Composites, 35: 318-326.

Cintia, F.do_C,. Monique de, A.S. 2012. Degradation of acidic solutions and bacterial adherence on the surface of indirect polymeric matrix. International Journal of Science Dentistry, 1: 47-54.

Callister, W.D. Jr. 2007. Materials Science and Engineering. $7^{\text {th }}$ edition, John Wiley $\&$ Sons, Inc., USA.

Dheyaa, B.M., Mnajid, A.H. 2012. The eEffect of liquids absorption on some mechanical and thermal properties for polymeric composites. In: Proceeding of International Conference on Engineering and Information Technology, ICEIT, ISBN:978-177136-064-7, pp.121-125, Toronto, Canada.

Geon, W.L., Min, P., Jun, K.K., Jae, I.K.L., Ho, G.Y. 2006. The enhanced thermal conductivity of polymer composites filled with hybrid filler. Applied Science and Manufacturing, 37: 727-734.

Hameed, T.M., Deyaa, B.M. 2016. A study of the effect of nanomaterials on the physical properties of Epoxy Blends, M.Sc. Thesis, Department of Applied 
Science, University of Technology, Iraq.

Hadi, B.H., Alradha, R.M. 2016. The effect of utilization silicon and copper powders at the properties for epoxy resin (mechanical and physical). Advances in Natural and Applied sciences, 10: 37.

John, H.L.I.V. 2000. A Heat Transfer Text Book, $3^{\text {rd }}$ edition, Lienhard, V. Phlogiston, Cambridge University Press, Massachusetts, USA.

Ledjane, I.S., Marysiliva, F. 2009. The effect of water absorption on an vinyl ester resin system. Material Research, 12: 353-361.

Macutkevic, J., Banys, J. 2013. Epoxy resin/carbon black composites below the percolation threshold. Journal of Nanoscience and Nanotechnology, 13: 5434-5439.

Ranta, A.A., Triaminingsih, S., Eriwati, Y.K. 2017. The effect of prolonged immersion of giomer bulk-fill composite resin on the $\mathrm{PH}$ value of artificial saliva and resin surface roughness, IOP science. Journal of Physics, Conference Series, 884: conference 1. Saijai, T., Boonlert, K., Thanwalee, P., Nilobon, C., Parnchanok, C. 2016. Surface roughness and erosion of nanohybrid and nanofilled resin composites after immersion in red and white wine. Journal of Conservative Dentistry, 19: 51-55.

Vouyovitch, L.N.D., Alberola, L., Flandin, A., Beroualand, J.L., B. 2006. Dielectric breakdown of epoxy - based composites, relative influence of physical and chemical aging, IEEE. Transactions on Dielectrics and Electrical Insulation, 13: 282292.

Zaman, H.U., Hun, P.D., Khan, R.A., Yoon, K.B. 2012. Morphology, mechanical and crystallization behaviours of micro-and nano $\mathrm{ZnO}$ filled polypropylene composites. Journal of Reinforced Plastic and Composites, 31: 323-329. 